This work is licensed under Creative Commons Attribution 4.0 International (CC BY 4.0).

[http://creativecommons.org/licenses/by/4.0/]

\title{
Różnice między katolicyzmem i prawosławiem w rozważaniach klasycznych i późnych słowianofilów rosyjskich (na przykładzie tekstów Iwana Kiriejewskiego i Nikołaja Danilewskiego)
}

Dorota Walczak | Uniwersytet Warszawski, Wydział Historyczny https://orcid.org/0000-0001-6109-6673

Słowa kluczowe:

słowianofilstwo, prawosławie,

katolicyzm, Iwan Kiriejewski, Nikołaj Danilewski

\section{Streszczenie}

Jedną z trzech głównych koncepcji rosyjskich słowianofilów było zdecydowane przeciwstawienie Rosji Europie, tłumaczone przez nich oczywiście na korzyść tej pierwszej. „Europa” w pojęciu słowianofilów stawała się nośnikiem negatywnych cech moralnych i przykładem zepsucia obyczajów. Przedmiotem porównania Europy z Rosją były niemal wszystkie dziedziny życia. Z oczywistych względów słowianofile wskazywali także na różnice religijne, wykazując wyższość prawosławnej Rosji nad katolicką lub protestancką Europą. Myśl słowianofilska, rozwijająca się w Rosji od połowy lat 20. aż do lat 60. i 70. XIX wieku w toku swojego rozwoju przeszła jednakowoż dość znaczącą ewolucję. Niniejszy artykuł ma na celu wykazanie, jaka jest różnica w postrzeganiu odmienności religijnych pomiędzy Rosją i Europą u tzw., klasyków słowianofilstwa oraz u późnych słowianofilów, wyznawców tzw. poczwienniczestwa. Przedmiotem porównania będą tu z jednej strony poglądy twórcy podwalin ideologii słowianofilskiej Iwana Kiriejewskiego oraz idee późnego teoretyka słowianofilstwa Nikołaja Danilewskiego.

Differences between catholicism and ortodoxy in concepts of classical and late russian slavophiles (on the example of Ivan Kireyevsky's and Nikolay Danilevsky's texts)

Summary

Keywords: One of the three main concepts of the Russian Slavophiles was to oppose Russia and Europe, of course, in favor of the Russia. "Europe" in the Slavophile concepts became a carrier of negative qualities and example of "corruption of morals", in contrast to Orthodox Russia, which draws from the heritage of the Orthodox faith. The subject of the comparison of Europe and Russia were almost all areas of political and social life. For obvious reasons, Slavophiles also pointed to religious differences, demonstrating the superiority of "Orthodox" Russia over the "Catholic" or "Protestant „Europe. In the course of its development Slavophile thought, growing in Russia since the mid-20s 
until the 60 s and 70s the nineteenth century, was undergone some evolution. This article is intended to demonstrate the difference between the perception of religious differences between Russia and Europe by so-called "classic Slavophiles" and in the late Slavophiles. The subject of comparison will be here on the one hand the views of the creator of the foundations of the lavophile ideology, Ivan Kireyevsky, and the ideas of the late Slavophile theoretician, Nikolay Danilevsky.

\section{Wstęp}

Profesor Andrzej Walicki w swojej klasycznej już pracy W kręgu konserwatywnej utopii: struktura i przemiany rosyjskiego słowianofilstwa podkreśla, że jednym z głównych założeń ideologii słowianofilów rosyjskich było zdecydowane przeciwstawienie Rosji i Europy i w porównaniu tym lepszą stroną okazywała się oczywiście Rosja (Walicki 2002: 14). Trzeba zaznaczyć, iż przedmiotem owego porównania Europy z Rosją stały się niemal wszystkie dziedziny życia, w tym także sfera religii. Słowianofile zawsze podkreślali moralną wyższość „prawosławnej” Rosji nad „katolicką" lub „protestancką" Europą, naznaczoną już, ich zdaniem, piętnem rozkładu. W niniejszym artykule podjęto próbę pokazania ewolucji w postrzeganiu różnic religijnych pomiędzy Rosją i Europą u tzw. klasycznych słowianofilów, reprezentowanych przez Iwana Kiriejewskiego, oraz u tzw. poczwienników, do których należał Nikołaj Danilewski.

\section{Iwan Kiriejewski: prawosławie jako religia integralna}

Iwan Wasilewicz Kiriejewski (1806-1856) obok Aleksieja Chomiakowa i Konstantina Aksakowa był jednym z głównych twórców ideologii słowianofilskiej. W młodości myśliciel przejawiał sympatie prozachodnie, podczas studiów na Uniwersytecie Moskiewskim był związany z kółkiem tzw. lubomudrów, interesujących się filozofią niemieckiego romantyzmu. W okresie nauki Kiriejewski odbył podróż do Niemiec, podczas której spotkał się osobiście m.in. z Schellingiem i Heglem.

Dzięki dogłębnym studiom nad filozofią romantyzmu niemieckiego Kiriejewski dobrze przyswoił sobie heglowski schemat, według którego historia jest procesem rozwoju absolutnej idei i w owym procesie rozwojowym poszczególne narody przejmują po sobie przewodnictwo. Analizując sytuację w Europie w pierwszych dziesięcioleciach XIX w., filozof doszedł do wniosku, że w tej swoistej sztafecie przyszła kolej na Rosję, której zadaniem jest wyprowadzenie Europy ze ślepej uliczki upadku moralnego (Долгушин 2009: 202-203). Szczególną rosyjską misję dziejową myśliciel dostrzegł w opracowaniu nowej filozofii, opartej na prawosławiu (Walicki 2002: 117). Już we wczesnym okresie twórczości Kiriejewski twierdził, że Rosja dysponuje samoistną tradycją kulturową, która została przechowana przez lud i jest zasadniczo różna od cywilizacji europejskiej. Według myśliciela podstawową cechą cywilizacji rosyjskiej była jej integralność. Od czasu swojego zwrotu ku prawosławiu, który dokonał się za sprawą żony, Natalii Pietrowny, Kiriejewski poświęcał kwestiom religijnym bardzo wiele uwagi. Małżonkowie wielokrotnie pielgrzymowali do Pustelni Optyńskiej, 
gdzie spotykali się z cieszącym się niezwykłym autorytetem mnichem, ojcem Makarym (Bezwiński 1993: 127).

Kiriejewski negatywnie oceniał chrześcijaństwo zachodnie, uważając je za „skażone” niszczącym je od wewnątrz duchem racjonalizmu (Благова 1995: 36). Sądził, że Europa Zachodnia jest chora moralnie i jeśli chce się wyleczyć, powinna czerpać z duchowości wschodniego chrześcijaństwa - prawosławia (Каменский 2003: 36). Swoje najważniejsze poglądy na temat różnic pomiędzy Europą i Rosją, w tym także różnic religijnych, Kiriejewski wyraził w liście skierowanym do hrabiego J.J. Komarowskiego (1856 r.). Myśliciel wymienił tam trzy czynniki, które jego zdaniem miały zasadniczy wpływ na wykształcenie się różnic pomiędzy kulturą rosyjską a kulturą europejską. Według Kiriejewskiego ogromne znaczenie dla przebiegu owego procesu miały czynniki etniczne, odmienność charakteru narodowego, ale największe znaczenie przypisywał drodze przyjęcia chrześcijaństwa, obecności lub braku dziedzictwa antycznego oraz sposobowi wykształcenia się państwowości na danym terenie (Киреевский 1984: 206). Nie sposób nie zauważyć, że to właśnie czynnik religijny autor wymienia na pierwszym miejscu, tym samym podkreślając jego szczególną wagę.

Wskazując na teoretyczną wspólnotę wiary pomiędzy Rosją a państwami europejskimi, będącymi wszakże również krajami chrześcijańskimi, Kiriejewski podkreślał, że najistotniejszą różnicą między nimi jest droga, jaką dotarła do nich owa religia. Chrześcijaństwo zostało przeniesione, zapośredniczone zarówno na Ruś, jak i na Zachód Europy. Główna różnica polega jednak na tym, że na ziemie ruskie zostało ono przeniesione via Bizancjum, a do krajów zachodnich - via Rzym.

Wychodząc od określonych przez siebie różnic mentalnych pomiędzy poszczególnymi narodami, autor utrzymywał, że teologowie różnych narodowości dostrzegali i rozwijali różne aspekty chrześcijaństwa:

Rzecz jasna, żaden patriarchat, żadne plemię, żaden kraj świata chrześcijańskiego, uczestnicząc przy tym we wspólnym życiu całego Kościoła, nie tracił swoich szczególnych właściwości [...] I tak teologowie w krajach syryjskich zwracali, jak się wydaje, uwagę przede wszystkim na wewnętrzne, kontemplacyjne życie człowieka, wyrzekającego się świata. Teologowie rzymscy z kolei zajmowali się w sposób szczególny działalnością praktyczną i logicznym związkiem pojęć. Pisarze duchowni cywilizowanego Bizancjum bardziej niż inni mieli, jak się zdaje, na uwadze stosunek chrześcijaństwa do poszczególnych nauk, które rozwijało się obok niego i początkowo były mu wrogie, potem zaś zostały mu podporządkowane. Teologowie aleksandryjscy, prowadzący walkę na dwie strony - z pogaństwem i judaizmem, otoczeni przez szkoły filozoficzne, teozoficzne i gnostyckie - zwracali uwagę przede wszystkim na kontemplacyjny aspekt nauki chrześcijańskiej (Киреевский 1984: 206-207)'.

Jeśli zatem przyjąć za Kiriejewskim, że Europa Zachodnia chrystianizowała się jedynie pod wpływem Rzymu, to była uboższa od Rusi, która za pośrednictwem Bizancjum przyswoiła sobie wpływy całego Wschodu chrześcijańskiego.

\footnotetext{
${ }^{1}$ Wszystkie cytaty ze źródeł rosyjskojęzycznych są przytaczane w tłumaczeniu autorki artykułu.
} 
Według autora lokalne, narodowe Kościoły chrześcijańskie pierwotnie się dopełniały i tworzyły wspólnie harmonijną całość. Pojedyncze, sporadycznie pojawiające się ruchy heretyckie miały być pokonywane poprzez kolektywną świadomość chrześcijańskiej jedności - „jednomyślnością Kościoła Powszechnego łączącego wszystkie pojedyncze kościoły w jednej świętej zgodności" (Киреевский 1984: 207). Zwraca uwagę fakt, że Kiriejewski odwoływał się do rozumienia Kościoła jako wspólnoty wszystkich wiernych - rozumienia, które inny teoretyk wczesnego słowianofilstwa, Aleksiej Chomiakow, określał terminem соборность (sobornost). Poszczególne kościoły narodowe wolały wyrzec się swoich poglądów, niż doprowadzić do podziału chrześcijaństwa. Taka sytuacja zdaniem Kiriejewskiego trwała bardzo długo, bo aż do czasu schizmy wschodniej (1054 r.). Odpowiedzialnością za ów rozłam myśliciel obarczył jedynie Kościół rzymskokatolicki, który według niego z własnej woli „oddzielił się od Kościoła powszechnego" (Киреевский 1984: 207). Za przyczynę schizmy Kiriejewski uznawał zbytnie skupienie się katolików na zewnętrznej stronie religii, pisząc: „Możliwe nawet, że to owa rzymska swoistość, owa oderwana rozsądkowość owa nadmierna skłonność do zewnętrznego łączenia pojęć była jedną z głównych przyczyn oderwania się Rzymu" (Киреевский 1984: 212).

„Racjonalizm” rzymskiej kultury siłą rzeczy miał kierować się nie ku duchowości, lecz ku zewnętrznym przejawom religijności. Katolicka teologia w opinii Kiriejewskiego była jednostronna i miała powierzchowny charakter. Autor dostrzegał, że zachodni teologowie mogli utożsamiać jedność Kościoła z czysto zewnętrzną jednością biskupstwa rzymskiego, a nie z jednością duchową, która z kolei doprowadziła do uznania nieomylności papieża (Киреевский 1984: 212). Podobnie racjonalistyczny charakter miała mieć cała teologia katolicka, uznająca za podstawę zbawienia nie myśli człowieka, ale jego wymierne uczynki (Киреевский 1984: 212).

Kiriejewski uważał, że sam Kościół katolicki jest odpowiedzialny za reformację. Jego zdaniem oczywiste jest, że nadmierny racjonalizm i zewnętrzna logika Kościoła rzymskiego musiały spowodować reakcję, która przyjęła formy jeszcze bardziej skrajnego racjonalizowania: „Kościół Zachodni już w IX wieku zasiał w swoim wnętrzu ziarno nieuniknionej reformacji" (Киреевский 1984: 212) - pisał filozof.

Zupełnym przeciwieństwem katolicyzmu jest zdaniem myśliciela prawosławie, czysta wiara chrześcijańska, od której oderwał się Kościół rzymski. Chrześcijaństwo, wedle Kiriejewskiego, stanowiło samo w sobie antytezę zdroworozsądkowej, racjonalistycznej kultury rzymskiej, która następnie przeszła do katolicyzmu (Киреевский 1984: 211). Prawosławie - pierwotne nieskażone chrześcijaństwo - miało się odznaczać bogactwem duchowym, a nie wyszukaną formą zewnętrzną (Киреевский 1984: 221). Kiriejewski pisze, że tylko na Wschodzie religia chrześcijańska zachowała się w czystej formie (Киреевский 1984: 219). Jego zdaniem teologowie prawosławni nie wymyślali nowych koncepcji, ale zgłębiali dogmaty chrześcijańskie, podążając drogą wytyczoną przez poprzedników: 
U pisarzy Kościoła Wschodniego, żyjących po oddzieleniu się Kościoła rzymskiego, nie można znaleźć niczego nowego odnośnie nauki chrześcijańskiej, niczego, co nie byłoby już obecne u pisarzy pierwszych wieków. Lecz na tym właśnie polega ich wartość, na tym, jak mówię, polega ich swoistość - że zachowali i utrzymali w czystości i integralności prawdziwie chrześcijańską naukę, pozostawali w samym, by tak rzec, centrum prawdy, skąd mogli wyraźniej widzieć zarówno prawa ludzkiego rozumu, jak i drogę prowadzącą do prawdziwej wiedzy, a także zewnętrzne przejawy oraz wewnętrzne sprężyny różnego rodzaju odstępstw od niej (Киреевский 1984: 220-221).

Kiriejewski uważał, że w przeciwieństwie do katolicyzmu prawosławie nie dążyło do zdobycia władzy politycznej: „Kościół prawosławny nie przyznawał charakteru religijnego instytucjom świeckim, takim jak zakony rycerskie, sądy inkwizycyjne czy inne instytucje duchowno-świeckie na Zachodzie" (Киреевский 1984: 225). Cerkiew prawosławna nie godziła się także na łączenie państwa z Kościołem, w zdecydowany sposób rozgraniczając sfery działania władcy i duchownych (Киреевский 1984: 225).

Wedle Kiriejewskiego chrześcijaństwo w Rosji nie było wprowadzane przemocą, tak jak miało to miejsce na Zachodzie, ale zostało przyjęte dobrowolnie, gdyż same cechy narodu rosyjskiego sprzyjały jego rozwijaniu:

Czystemu wpływowi jego nauki na życie wewnętrzne i społeczne człowieka świat słowiański nie stawiał takiego nieprzejednanego oporu, jaki napotykało chrześcijaństwo w zamkniętej strukturze świata klasycznego oraz w jednostronnej kulturze narodów zachodnich. W znacznej mierze szczególne cechy plemienne obyczajowości słowiańskiej sprzyjały pomyślnemu zakorzenieniu się w niej pierwiastków chrześcijańskich (Киреевский 1984: 208).

Myśliciel uważał cały ustrój społeczny Rosji za z gruntu chrześcijański, zachowany w nienaruszonym stanie do czasów mu współczesnych, pisząc:„Rdzeń cywilizacji Rosji żyje ciągle wśród jej ludu, i co najważniejsze, żyje w jej świętym Kościele prawosławnym" (Киреевский 1984: 237).

\section{Nikołaj Danilewski: polityzacja wiary}

Poglądy teoretyków późnego słowianofilstwa na różnice pomiędzy katolicyzmem i prawosławiem były znacznie bardziej pragmatyczne i racjonalne niż koncepcje idealisty Kiriejewskiego. Nikołaj Jakowlewicz Danilewski (1820-1885) był przedstawicielem drugiej generacji słowianofilów, tzw. poczwienników. O przemianie, jaka dokonała się w ruchu słowianofilskim na przestrzeni dwudziestu lat, najdobitniej świadczy fakt, że wielu współczesnych Danilewskiemu rosyjskich intelektualistów w ogóle nie chciało uznawać go za słowianofila - tak silnie raziła ich głoszona przez autora apologia samodzierżawia i wyrachowanie polityczne (Цимбаев 1986: 75). Bardzo znamienne jest, że Danilewski z wykształcenia był nie humanistą, lecz biologiem, i większość jego prac naukowych poświęconych jest botanice i rybołówstwu. W młodości miał poglądy rewolucyjne, był zwolennikiem furieryzmu. Zatrzymany w $1847 \mathrm{r}$. w związku 
z działalnością w antycarsko nastawionym kółku pietraszewców spędził trzy miesiące w więzieniu, a później został zesłany w głąb Rosji, gdzie znalazł pracę jako urzędnik Departamentu Rolnictwa. Często uczestnicząc w ekspedycjach naukowych, badających stan rolnictwa i rybołówstwa w różnych rejonach Imperium Rosyjskiego, Danilewski jednocześnie pisał prace teoretyczne. W 1866 r. napisał swoje najważniejsze dzieło - książkę historyczno-polityczną Rosja i Europa. Pogląd na kulturalne i polityczne stosunki świata słowiańskiego z germańskoromańskim (ros. Россия и Евроna. Взгляд на культурные и политические отношения Славянского мира к Германо-Романскому). Praca owa, wydana po raz pierwszy w 1869 r., stanowi swoiste ukoronowanie rozwoju myśli słowianofilskiej i została przyjęta z zachwytem przez sympatyzującego z ideami słowianofilów Fiodora Dostojewskiego (Lazari 2000: 86-87). Wielu badaczy uważa także, że na formowanie się poglądów Danilewskiego o Europie ogromny wpływ miała wcześniejsza publicystyka Dostojewskiego (Балуев 2001:226). Autor Rosji i Europy podbudował swoje imperialne idee teorią opartą na popularnym wówczas organicyzmie - porównywaniu rozwoju poszczególnych ludów do rozwoju biologicznego organizmów żywych (Diec 2002: 10). Uczony wyróżniał w historii twory, zwane przez siebie „typami kulturalno-historycznymi" (ros. культурно-исторические munы). Owo pojęcie obejmuje całokształt rozwoju religijnego, społecznego, przemysłowego, politycznego, naukowego, artystycznego i historycznego, cechującego dany naród lub grupę narodów (Султанов 2001: 60). Danilewski uznawał Słowian, na równi z ludami germańsko-romańskimi, za osobny typ kulturalno-historyczny, który ma swoje osobne zadanie do zrealizowania. Jednocześnie uznawał, że cele i zadania Germanów i Romanów („Europy”) są przeciwstawne do celów Rosjan („świata słowiańskiego") i oba te typy kulturowe są sobie wrogie. Zakładał, że Rosja powinna stworzyć federację państw słowiańskich - Związek Wszechsłowiański - w którym obejmie rolę hegemona. Co prawda słowianofile zawsze kładli nacisk na konieczność zbliżenia prawosławnych narodów słowiańskich, ale wcześniej nie wysuwali w sposób tak wyraźny idei zjednoczenia politycznego. Sytuację zmieniły wojna krymska (1853-1856) i późniejszy konflikt na Bałkanach (1875-1878) (Giza 1982: 10-11).

Uczony starał się w możliwie jaskrawy sposób przedstawić różnice pomiędzy Europą i Rosją. Różnicom religijnym poświęcił cały rozdział IX, w którym próbował udowodnić, że prawosławie i katolicyzm są bardzo dalekie od siebie, pomimo że pozornie różnice dogmatyczne pomiędzy nimi wydają się mało istotne, mniejsze niż pomiędzy katolicyzmem i wyznaniami protestanckimi. Autor na wstępie w wyraźny sposób określił swoją pozycję, pisząc, że dla człowieka wierzącego różnica między katolicyzmem i prawosławiem jest oczywista, a swoją dalszą argumentację kieruje do sceptyków:

Na to można byłoby odpowiedzieć bardzo krótko, mianowicie: że różnica między prawdą i kłamstwem jest nieskończona i dwa kłamstwa zawsze mniej różnią się między sobą, niż każde z nich od prawdy, lecz ta odpowiedź byłaby zadowalająca jedynie dla tych, którzy nawet jej nie potrzebują, a dla tych którzy w trzech wymienionych formach chrześcijaństwa widzą nie więcej, niż formalną różnicę (Данилевский 1991: 199). 
Interesujący wydaje się fakt, że chociaż Danilewski był zwolennikiem darwinizmu i w swojej pracy, opisując ewolucję narodów i ich wzajemną rywalizację, zastosował teorię Darwina, nie poszedł w ślady swojego mistrza i nie odrzucił koncepcji o ingerencji siły wyższej w bieg dziejów. Kwestię ową uczony starannie omija, a w samym tekście wielokrotnie podkreśla swoje przywiązanie do prawosławia (Авдеева 1992: 66).

Odwołując się do Chomiakowa, Danilewski zauważa, że pomimo formalnego podobieństwa, bo przecież katolicyzm, prawosławie i protestantyzm mają to samo wyznanie wiary, w zupełnie różny sposób pojmują jego treść:

Istota dogmatyki chrześcijańskiej została wyłożona w wyznaniu wiary i rzeczywiście my wszyscy, prawosławni, katolicy, protestanci, czytamy to wyznanie niemal tak samo, łącząc jednak zupełnie inne znaczenie ze słowami: Wierzę w jeden święty i apostolski Kościół (Данилевский 1991: 200).

Główną różnicę pomiędzy Kościołami chrześcijańskimi Danilewski dostrzega w stosunku do Objawienia oraz rozumieniu pojęcia "Kościoła” $\mathrm{i}$ dogmatu o jego nieomylności. Opierając się na wskazanych przez siebie kryteriach, badacz wymienia cztery postawy: postawę prawosławną, ,"wedle której Kościół to wspólnota wszystkich wierzących pod wodzą Jezusa Chrystusa i przewodnictwem Ducha Świętego, przypisujące tak rozumianemu Kościołowi nieomylność", postawę katolicką, ,"kumulującą pojęcie o Kościele w osobie papieża i dlatego przypisujące mu właśnie nieomylność", postawę protestancką „przenoszącą na każdego wiernego ową nieomylność, oczywiście w stosunku do siebie samego, lub, co na to samo wychodzi, odrzucającą nieomylność kogokolwiek" oraz postawę kwakrów i metodystów, "którą można nazwać mistyczną, jako że stawia nieomylność $w$ zależność od bezpośredniego oświecenia każdego wiernego przez Ducha Świętego" (Данилевский 1991: 201).

Danilewski nie omawiał postawy mistycznej ze względu na jej marginalne znaczenie, ale dokładniej zajął się omówieniem postaw katolickiej i protestanckiej. Zdaniem autora podejście protestantów do religii prowadzi do jej subiektywizacji - każdy z wiernych może sam objaśniać Biblię i wybierać z niej tylko odpowiadające mu fragmenty (Данилевский 1991: 202). Jego zdaniem poszczególne wyznania protestanckie - kalwinizm, luteranizm, anglikanizm - powstały, by walczyć z dowolnością dogmatyczną. Danilewski w gruncie rzeczy stawia znak równości pomiędzy wybiórczą wiarą protestancką a wyborem elementów biblijnych dokonanym przez Renana ${ }^{2}$.

W kwestii katolicyzmu autor twierdził, że nie można mu zarzucić niekonsekwencji i wewnętrznej sprzeczności dogmatycznej, lecz nie można także udowodnić jego słuszności. Zdaniem Danilewskiego obalenie dogmatu o nieomylności papieży jest bardzo łatwe - wystarczy przeprowadzić badania źródłowe nad historią papiestwa

\footnotetext{
${ }^{2}$ Ernest Renan był francuskim pisarzem, autorem opublikowanej w 1861 r. książki Żywot Jezusa, w której przedstawił Chrystusa jako postać historyczną, nieobdarzoną cechami boskimi. Żywot Jezusa był silnie krytykowany zarówno przez środowiska katolickie, jak i prawosławne (m.in. przez Fiodora Dostojewskiego).
} 
i przywołać kilka szczególnie jaskrawych przypadków, dotyczących popełnionych przez nich błędów. Agresywna postawa Kościoła katolickiego i jego dążenie do sprawowania całkowitej kontroli nad życiem wiernych zdaniem Danilewskiego postawiła państwa katolickiej Europy przed trudnym wyborem:

Katolickie narody zostały zmuszone do wybrania jednego z trzech: albo wyrzec się owoców, wypracowanych krwią i potem wielowiekowej walki i wielowiekowej pracy i wrócić do czasów Grzegorza VII lub Urbana II, albo wyrzec się katolickiego rozumienia Kościoła i, co za tym idzie, albo wejść na śliską drogę protestantyzmu, albo powrócić na łono prawosławia, albo, na koniec, wyrzec się razem z katolicyzmem i samego chrześcijaństwa (Данилевский 1991: 208).

Wedle myśliciela narody Europy skłaniają się do tej ostatniej opcji, postulując uwolnienie państwa od Kościoła, co z kolei prowadzi do postępującej laicyzacji i ateizacji. Jako przykład Danilewski podaje popularne w Europie Zachodniej śluby cywilne, które nie są oparte na żadnej podstawie religijnej, a więc są pozbawione moralnej podpory. Wedle jego opinii, jeśli małżeństwo jest jedynie umową między ludźmi, to nie istnieje żaden racjonalny powód, żeby nie pozwolić na wielożeństwo.

Według autora żadne przeciwieństwa czy ciężar dla wiernych nie wiążą się jedynie z prawosławiem. Jedynie Cerkiew prawosławna jest nieomylna, ponieważ „nieomylność owa wyraża się we wszystkim tym, co składa się na głos całej Cerkwi, i, co za tym idzie, w najbardziej jasny i wyraźny sposób na soborach powszechnych" (Данилевский 1991: 214). Rozwijając koncepcję sobornosti Chomiakowa, Danilewski utrzymywał, że żaden oddzielny władca czy hierarcha cerkiewny nie może sam nadać soborowi rangi soboru powszechnego (Данилевский 1991: 215). Działanie soborów powszechnych ma zdaniem uczonego moc sprawczą, gdyż, na przykład, wypowiedziana przez sobór anatema na ruchy heretyckie powodowała ich szybkie zniknięcie (Данилевский 1991:215). Także wolność Kościoła od państwa w krajach prawosławnych jest jego zdaniem oczywista:

Granica pomiędzy należącym do Boga i należącym do Cezara, przegroda pomiędzy królestwami obu światów nie może zostać naruszona, dlatego że sama Cerkiew we wszystkim, co się do niej odnosi, jest nieomylna, nigdy nie może jej przekroczyć, jeśli zaś niekiedy przekracza ją państwo, to jest to nie więcej niż odosobnienie i czasowa przemoc, która, co prawda, może spowodować nieszczęście lub cierpienie poszczególnych chrześcijan, hierarchów, a nawet całych ludów, lecz jest zupełnie bezsilna wobec Cerkwi w ogóle (Данилевский 1991: 215-216).

Swój wywód Danilewski zakończył konstatacją, że Cerkiew prawosławna jest jedyną, w ramach której można osiągnąć zbawienie. Katolicyzm i protestantyzm poprzez swoją wewnętrzną sprzeczność i wybiórczość traktowania dogmatów nie są wiarygodne dla wiernych, a więc prowadzą ich do zwątpienia w istnienie Boga, a w konsekwencji do ateizmu. Jeśli Kiriejewski sądził, że Rosja powinna uratować kraje europejskie poprzez przekazanie jej zachowanego przez siebie czystego chrześcijaństwa, Danilewski nie widzi ratunku dla zagrożonej ateizacją Europy: 
Cóż z tym robić? Czyż jest wyjście? Dla pojedynczych ludzi, łaknących prawdy - tak, bramy prawosławia są dla nich otwarte. Dla całych narodów prawdopodobnie nie ma prostego, bezpośredniego wyjścia; muszą najpierw przejść przez wszystkie stopnie zgrzybiałości, choroby, śmierci i rozkładu, żeby z uzyskanych w wyniku ich rozkładu elementów powstała nowa całość etnograficzna, nowy typ kulturalno-historyczny (Данилевский 1991: 218).

\section{Od prawosławnego idealizmu do polityzacji wiary}

Iwan Kiriejewski uznawał, że zachodnie chrześcijaństwo jest skażone racjonalizmem, zbyt silnie powiązane z władzą świecką oraz ma charakter wyłącznie zewnętrzny, prawosławie jest natomiast religią integralną i harmonijną, co czyni z niego jedyną czystą formę chrześcijaństwa. Misję Rosji stanowi jego zdaniem przechowanie prawosławia i przekazanie go w nienaruszonym stanie Europie Zachodniej, aby uleczyć ją od choroby „abstrakcyjnego myślenia”, prowadzącej do stopniowej ateizacji i upadku duchowego. Postawę Kiriejewskiego można określić mianem „prawosławnego mesjanizmu”. Wybitny polski historyk Marian Zdziechowski w ogóle utożsamił klasyczne słowianofilstwo z mesjanizmem (Zdziechowski 1888: VI). Owa postawa mesjanistyczna w słowianofilstwie rosyjskim z biegiem czasu stopniowo traci na znaczeniu i w zupełności zanika u poczwienników. Nikołaj Danilewski wysuwał na pierwszy plan nie tyle różnice mentalne, co niezgodności dogmatyczne. Uznawał, że kluczowe znaczenie ma różnica w pojmowaniu pojęcia „Kościół” przez prawosławie, katolicyzm i protestantyzm. Katolickie i protestanckie rozumienie owego terminu uważał za sprzeczne wewnętrznie, i dlatego prowadzące do stopniowej utraty wiary przez mieszkańców Europy Zachodniej. Danilewski uważał, że proces ów jest nieodwracalny, i Rosja nie może pomóc krajom europejskim, przekazując im czyste prawosławie. Autor wróżył Europie szybką katastrofę i dość cynicznie stwierdzał, że co najwyżej na jej gruzach może powstać jakaś nowa, lepsza cywilizacja. Zupełnie obca jest mu idea uniwersalizmu, potrzeba niesienia innym narodom prawdziwej wiary, tak silnie przejawiająca się u klasycznych słowianofilów.

Podczas gdy dzieło Kiriejewskiego jest tekstem o charakterze filozoficznym, w którym autor wyraża idee, w których prawdziwość wierzy, Danilewski rości sobie prawa do naukowości i przyjmuje głoszone przez siebie poglądy za naukowo udowodnione i niezbite, podbudowując je licznymi przykładami z historii. Pierwsi słowianofile chwalili religijność prostego ludu rosyjskiego, przeciwstawiając się jednocześnie oficjalnej Cerkwi, skażonej zachodnim racjonalizmem, a także dystansowali się wobec władzy carskiej (Дудзинская 1983: 33-34). Danilewski głosi apologię zarówno oficjalnego prawosławia, jak i władzy samodzierżawnej. Jego program zjednoczenia Słowiańszczyzny ma charakter nie tyle religijny i duchowy, co polityczny.

Zmiana, która dokonała się na przestrzeni dziesięciu lat dzielących teksty Kiriejewskiego i Danilewskiego w poglądach słowianofilów na różnice religijne pomiędzy Europą Zachodnią i Rosją jest naprawdę porażająca. Andrzej Walicki pisze, że podczas gdy klasyczni słowianofile chcieli bronić zasad prawosławnej integralności ducha i głosić je 
Europie, a ich cele leżały jedynie w sferze religijno-ideologicznej, Danielewski wysuwał niemal wyłącznie cele polityczne, głosząc konieczność stworzenia silnego państwa słowiańskiego (Walicki 2002: 370). Można powiedzieć, że zmienił on najwyższy punkt odniesienia - z prawosławia na "słowiańskość" (Walicki 2002: 371).

\section{Bibliografia}

Авдеева Л.Р., 1992, Русские мыслители: Ап. А. Григорьев, Н. Я. Данилевский, Н. Н. Страхов: философская культурология второй половины XIX века, Москва.

Балуев Б.Р., 2001, Споры о судьбах России: Н. Я. Данилевский и его книга «Россия и Европа», Тверь. Bezwiński A., 1993, Iwan Kiriejewski - krytyk i myśliciel (korzenie rosyjskiego nacjonalizmu), Toruń.

Благова Т.И., 1995, Родоначальники славянофилов: Алексей Хомяков и Иван Киреевский, Москва. Цимбаев Н.И., 1985, Славянофильство: из истории русской общественно-политической мысли ХІХ века, Москва.

Данилевский Н.Я., 1991, Россия и Европа. Взгляд на культурныя и политическия отношения Славянского мира к Германо-Романскому, Москва.

Diec J., 2002, Cywilizacje bez okien: teoria Mikołaja Danilewskiego i późniejsze koncepcje monadycznych formacji socjokulturowych, Kraków.

Долгушин Д.В., 2009, В. А. Жуковский и И. В. Киреевский: из истории религиозных исканий русского романтизма, Москва.

Дудзинская Е.А., 1983, Славянофилы в общественной борьбе, Москва.

Giza A., 1982, Słowianofile rosyjscy wobec kryzysu bałkańskiego w latach 1875-1878, Wrocław.

Каменский 3.А., 2003, Философия славянофилов: Иван Киреевский и Алексей Хомяков, Санкт-Петербург.

Киреевский И.В., 1984, О характере просвещения Европы и о его отношении к просвещению России [w:] Idem, Избранные статьи, Москва.

Lazari A., 2000, W kręgu Fiodora Dostojewskiego: poczwienniczestwo, Łódź.

Султанов К.В., 2001, Социальная философия Н.Я. Данилевского: конфлликт интерпретаций, Санкт-Петербург.

Walicki A., 2002, W kręgu konserwatywnej utopii: struktury i przemiany rosyjskiego słowianofilstwa, Warszawa.

Zdziechowski M., 1888, Mesyaniści i słowianofile: szkice z psychologii narodów słowiańskich, Kraków.

\section{Biogram}

Dorota Walczak - uzyskała magisterium z historii (2015), historii sztuki (2016) i filologii rosyjskiej (2018) na Uniwersytecie Warszawskim. Od 2015 r. jest doktorantką Wydziału Historycznego Uniwersytetu Warszawskiego. Jej obszarem zainteresowania są myśl filozoficzna, religijna i estetyczna w XIX-wiecznej Rosji. 